Preface

\title{
The variability of primary production in the ocean: From the synoptic to the global scale. The 45th International Liege Colloquium on Ocean Dynamics, Liege, Belgium, May 13-17, 2013
}

The 45th International Liege Colloquium on Ocean Dynamics (http://modb.oce.ulg.ac.be/colloquium/) gathered two hundred scientists from around the world to discuss new insights related to the evaluation of primary production at various spatial and temporal scales and in different regions of the world ocean (e.g., the polar and sea-ice region, the coastal and the deep ocean). Over the past two decades, substantial efforts were deployed to evaluate oceanic primary production. These efforts include in situ measurements of uptake rates using isotopic techniques, remote sensing, autonomous instrumentation for bio-optics, carbon or oxygen measurements, and the development of semiempirical to complex biogeochemical models. The colloquium presented the opportunity to review the current knowledge in the estimation of primary production, and to assess the impact of physical processes on ocean productivity. Particular attention was focused on the importance of physical processes at different spatial and temporal scales for controlling the level and variability of primary production and on the development of adequate methodologies to tackle this variability in order to derive large-scale, climate-driven budgets. Refined biogeochemical models considering for instance phytoplankton physiology, the representation of variable elemental stoichiometric ratios, the role of mixotrophy, as well as satellite algorithms that are now able to simulate the plankton functional types, are good candidates for scaling up. Contributions dealing with the difficult issue of interoperability of in-situ, satellite and modelling estimates of primary production were presented. Details on the terms of reference as well as the thematic session that were organized can be found at http://modb.oce.ulg.ac.be/?page $=$ colloquium\&year $=2013$.

The special issue presents a collection of papers dealing with these different themes. The issue is introduced by a review paper written by John Marra (2015-in this issue). His review highlights the progress that has been made in the knowledge of Ocean Productivity since the first Liège colloquium, 45 years ago. He emphasizes that the conclusions on net heterotrophy or net autotrophy of the open ocean are strongly dependent on the estimation of the depth of the euphotic zone, a deeper productive layer (compared to what is traditionally assumed) would favour net autotrophy. On the other hand, the paper points out that the quantity of fixed carbon that gets diverted to the dissolved pool (i.e., dissolved primary production) could have been underestimated in the past, complicating the view of the metabolic balance in the ocean. Merlivat et al. (2015-in this issue); Shadwick et al. (2015-in this issue) and Stanley et al. (2015-in this issue) estimated the net community production (NCP) using mass balance approaches of several tracers in different marine environments. Merlivat et al. (2015-in this issue) computed the NCP by mass balance of carbon dioxide $\left(\mathrm{CO}_{2}\right)$ from surface measurements from a drifter in a large area of the Southern Ocean $\left(38^{\circ} \mathrm{S}-55^{\circ} \mathrm{S}, 60^{\circ} \mathrm{W}-60^{\circ} \mathrm{E}\right)$ that represents nearly one third of the subantarctic zone. The comparison of the $\mathrm{CO}_{2}$-based NCP estimates with net primary production (NPP) derived from remote sensing data, suggests that satellite derived NPP is under-estimated and that Chlorophyll-a (Chl-a) data derived from SeaWIFS (Sea-Viewing Wide Field-of-View Sensor) need to be revised upwards in the Southern Ocean. In addition to $\mathrm{CO}_{2}$ measurements, Shadwick et al. (2015-in this issue) also use the oxygen argon ratio $\left(\mathrm{O}_{2} / \mathrm{Ar}\right)$ to derive NCP estimates in the Australian Sector of the Southern Ocean $\left(115^{\circ} \mathrm{E}\right.$, WOCE I9S). Their results suggest that near fronts, in ice covered areas, and in areas where surface temperature changes act on shorter timescales than the equilibration of mixed-layer $\mathrm{O}_{2}$ such that $\mathrm{O}_{2}$ may not be a good predictor of NCP. In addition to $\mathrm{O}_{2} / \mathrm{Ar}$, Stanley et al. (2015-in this issue) also use triple oxygen isotopes to derive NCP in the Beaufort Gyre (Arctic Ocean). They highlight strong inter-annual variability of NCP in the Beaufort Gyre by the comparison of low and record-low ice conditions of August 2011 and 2012. Cherrier et al. (2015-in this issue) and Craig et al. (2015-in this issue) reported on two important processes in the uptake of $\mathrm{CO}_{2}$ that are infrequently investigated. Cherrier et al. (2015-in this issue) carried out laboratory and field studies (Gulf of Mexico and Pacific Ocean) to examine the effects irradiance variability on the extracellular release (ER) of dissolved organic carbon (DOC) by phytoplankton and the response of natural bacteria assemblages. Their results indicate that release of DOC by phytoplankton as a function of incident irradiance can be significant and may have important implications for estimates of ocean carbon flux. Craig et al. (2015-in this issue) characterized seasonal patterns in phytoplankton community composition on the Scotian Shelf (northwest Atlantic Ocean), through a study of the numerical abundance of different cell sizes. They observed a persistent drawdown of $\mathrm{CO}_{2}$ throughout the summer months, despite nutrient limitation, in association with a plankton assemblage dominated by microphytoplankton. This study pointed to the important role that small cells play in annual $\mathrm{CO}_{2}$ uptake. Houliez et al. (2015-in this issue) report the results of the variability in photosynthetic parameters in natural populations, measured using pulse amplitude modulated (PAM) fluorometry. They characterize the variability from hourly to monthly time scales, and show how the photosynthetic response changes according to the scale considered. Campbell et al. (2015-in this issue) and Muacho et al. (2015-in this issue) report Chl-a dynamics in two contrasting marine environments. Campbell et al. (2015-in this issue) investigate the bottom ice Chl-a and snow depth (HS) relationship in first-year sea 
ice in Allen Bay (Arctic). Chl-a was related to HS according to four phases over the spring bloom period, each showing either no relationship or positive or negative relationships. These results indicate that bottom ice temperature and the rapid change in photosynthetically active radiation (PAR) at the ice bottom were the most important factors driving Chl-a loss from snow-free areas, most likely due to ice melt and potentially photoinhibition. Muacho et al. (2015-in this issue) used a multi-sensor satellite approach based on ocean colour, sunglint and Synthetic Aperture Radar (SAR) imagery to study the impact of interacting internal tidal (IT) waves on near-surface Chl-a distribution, in the central Bay of Biscay (European continental shelf). Results show that elevated IT activity in late summer plays a significant role in phytoplankton vertical distribution, and therefore influences the late summer ecology in the central Bay of Biscay. Kahru et al. (2015-in this issue) show that ocean colour data collected from different sensors (SeaWiFS, MODIS (Moderate Resolution Imaging Spectroradiometer) and MERIS (MEdium Resolution Imaging Spectrometer)) need to be reprocessed in order to derive unbiased estimates of oceanic primary production in the California current system. The study touches upon the important and challenging issue of creating climate data records of primary production from successive satellite missions that are reasonably accurate and, as importantly, consistent. Swart et al. (2015-in this issue) present a unique, highresolution glider data set collected in the Southern Ocean to assess the importance of mesoscale- to submesoscale processes in driving vertical stratification and early phytoplankton bloom initiation. This study underlines the need for climate models to resolve mesoscale to submesoscale and subseasonal variability in order to faithfully reproduce the sensitivity of ocean primary productivity to climate change. Ferrari et al. (2015-in this issue) challenge the critical depth hypothesis and show clear evidence that the surface concentration of phytoplankton increases rapidly when atmospheric cooling of the ocean turns into an atmospheric heating at the end of winter. Vaz et al. (2015-in this issue) describe a coupled physical-biological model applied to the coastal area at the outflow of the Tagus River, Portugal. The mouths of rivers have complex hydrography and biogeochemical response. Still, the authors are able to reproduce the main features in the biology, and show how the river plume shapes the ecosystem structure. Große et al. (2015-in this issue) propose a new parameterization of phytoconvection that they apply to a 3D model of the Northwestern European Continental Shelf. They found that the parametrization improves the vertical structure of winter Chl-a and notably enhances the export production. Finally, McKiver et al. (2015-in this issue) show that increasing grid resolution from $2^{\circ}$ to $1 / 4^{\circ}$ in a global biogeochemical model reduces some of the typical low resolution biases.

\section{Acknowledgments}

In the name of the Scientific Committee and of the local Organizing Committee, we thank the (F.R.S.-FNRS), the Ministry of Education and Research of the Wallonia-Brussels Region, the University of Liège, the Belgian Science Policy Office (BELSPO), the Gordon and Betty Moore Foundation (grant no. 3603), l'agence française de l'espace (CNES), L'Institut National des Sciences de l'Univers du Centre National français de la Recherche Scientifique (CNRS-INSU), the European Geophysical Union (EGU), the National Aeronautics and Space Administration (NASA) for their valuable support.

\section{References}

Campbell, K., Mundy, C.J., Barber, D., Gosselin, M., 2015. Characterizing the ice algae biomass-1 snow depth relationship over spring melt using transmitted irradiance. $147,76-84$ (in this issue).
Cherrier, J., Valentina, S.K., Hamill, B., Jeffrey, W.H., Marra, J.F., 2015. Light-mediated release of dissolved organic carbon by phytoplankton. 147, 45-51 (in this issue).

Craig, S.E., Thomas, H., Jones, C.T., Li, W.K.W., Greenan, B.J.W., Shadwick, E.H., Burt, W.J., 2015. The effect of seasonality in phytoplankton community composition on $\mathrm{CO}_{2}$ uptake on the Scotian Shelf. 147, 52-60 (in this issue).

Ferrari, R., Merrifield, S., Taylor, J., 2015. Shutdown of Convection Triggers Increase of Surface Chlorophyll. 147, 116-122 (in this issue).

Große, F., Pätsch, P., Lindemann, C., Walter, B., Backhaus, J., 2015. The influence of deep winter convection on primary production: a parameterisation using a hydrostatic 3D biogeochemical model. 147, 138-152 (in this issue).

Houliez, E., Lizon, F., Lefebvre, S., Felipe Artigas, L., Schmitt, F.G., 2015. Phytoplankton photosynthetic activity dynamics in a macrotidal ecosystem (the Strait of Dover, eastern English Channel): time scales of variability and environmental control. 147, 61-75 (in this issue).

Kahru, M., Jacox, M.G., Lee, Z., Kudela, R.M., Manzano-Sarabia, M., Mitchell, B.G., 2015. Optimized Multi-Satellite Merger of Primary Production Estimates in the California Current Using Inherent Optical Properties. 147, 94-102 (in this issue).

Marra, J., 2015. Ocean Productivity: A Personal Perspective Since the First Liege Colloquium. $147,3-8$ (in this issue)

McKiver, W.J., Vichi, M., Lovato, T., Storto, A., Masina, S., 2015. Impact of resolved physical dynamics on global marine, biogeochemistry. 147, 153-168 (in this issue).

Merlivat, L., Boutin, J., Antoine, D., 2015. Roles of biological and physical processes in 1 driving seasonal air-sea $\mathrm{CO}_{2}$ flux in the Southern Ocean: new insights from CARIOCA pCO 2 . 147, 9-20 (in this issue).

Muacho, S., da Silva, J.C.B., Brotas, V., Oliveira, P.B., Magalhaes, J.M., 2015. Chlorophyll enhancement in the central region of the Bay of Biscay as a result of internal tidal wave, interaction. 147, 85-93 (in this issue).

Shadwick, E.H., Tilbrook, B., Cassar, N., Trull, T.W., Rintoul, S.R., 2015. Summertime physical and biological controls on $\mathrm{O}_{2}$ and $\mathrm{CO}_{2}$ in the Australian sector of the Southern Ocean. 147, 21-28 (in this issue).

Stanley, R.H.R., Sandwith, Z.O., Williams, W., 2015. Rates of summertime biological productivity 1 in the Beaufort Gyre: a comparison between the low and record-low ice conditions of August 2011 and 2012. 147, 29-44 (in this issue).

Swart, S., Thomalla, S.J., Monteiro, P.M., 2015. The seasonal cycle of mixed layer dynamics and phytoplankton biomass in the sub-Antarctic zone: a high resolution glider experiment. 147, 103-115 (in this issue).

Vaz, N., Mateus, M., Plecha, S., Sousa, M.C., Leitão, P.C., Dias, J.M., 2015. Modeling SST and chlorophyll patterns in a coupled estuary-coastal system of Portugal: the Tagus case study. $147,123-137$ (in this issue).

Marilaure Grégoire Laboratoire d'Océanologie, B6c Sart-Tilman, Université de Liège, Belgium Corresponding author. E-mail address: mgregoire@ulg.ac.be.

Marina Lévy

Sorbonne Université (UPMC, Paris 6)/CNRS/UPMC/IRD/MNHN, Laboratoire d'Océanographie et du Climat (LOCEAN), Institut Pierre Simon Laplace (IPSL), 75252 Paris Cedex 05, France E-mail address: marina@locean-ipsl.upmc.fr.

John Marra

Department of Earth and Environmental Sciences, Brooklyn College of the City University of New York, F1000, Brooklyn, NY, USA E-mail address: jfm7780@brooklyn.cuny.edu. Chemical Oceanography Unit, B5 Sart-Tilman, Université de Liège, Belgium E-mail address: Alberto.Borges@ulg.ac.be.

Pierre Brasseur

CNRS, LGGE, F-38041 Grenoble, France E-mail address: Pierre.Brasseur@legi.grenoble-inp.fr. 